\title{
Reading Practices and Literacy of Boer Combatants in the South African War of 1899-1902
}

\author{
Fransjohan Pretorius \\ University of Pretoria, Republic of South Africa
}

\begin{abstract}
In investigating the reading practices of Boer combatants during the South African War diaries, letters and reminiscences were consulted. The state of literacy reveals a picture of a small number of highly literate men, a larger group of adequately literate men, a still larger group of semi-literates, and the illiterate. Reading matter included the Bible, newspapers and books. Issues raised are: Did literacy (or illiteracy) influence military decision-making or troop morale? Were certain works making some impact on the battlefield? Was the practical experience the Boers had gained before the war more successful in planning strategy and tactics than literacy?
\end{abstract}

Key words: Boer strategy and tactics; Boer literacy; military decision-making; reading matter; reading practices; South African War

\section{Introduction}

In the midst of daily duties life on commando during the South African War of 18991902 provided ample time for the Boers (burghers) for all manner of pastimes. Physical recreation consisted of swimming in the nearest river, participating in sports days with athletics, soccer and informal fun, cricket matches, boxing, wrestling and fishing. Of all the tranquil pastimes, resting and idling and strolling around the laager, discussing the war, were very popular. Laager industries - carving objects from wood or bone - thrived, and some burghers found card games a delightful pastime. ${ }^{1}$ Reading was another way to while away the time.

In order to determine what was read on commando and why this is important for us to know, a definition of literacy may provide some context. The USA's National Assessment of Adult Literacy defines literacy as both task-based and skills-based. The task-based definition of literacy, used in both the 1992 and 2003 assessments, focuses on the everyday literacy tasks an adult can and cannot perform. It is the ability to use printed and written information to function in society, to achieve one's goals, and to develop one's knowledge and potential. However, the 2003 NAAL adds a complementary skills-based definition of literacy that focuses on the knowledge and skills in order to perform these tasks. According to the skills-based definition successful use of printed material is a product of two classes of skills - word-level reading skills, and higher level literacy skills. ${ }^{2}$

The general skills-based literacy of the rank and file on commando and their reading practices during the war are well worth an investigation. This gives an 
indication of not only the kind of material that was available or read on commando, but also of the minds and psychological world of these men from the two small Boer republics who were prepared to fight against the leading nation of the world. Moreover, although the task-based literacy of the ordinary Boers (burghers) most probably did not affect the strategy and tactics of the war effort, the literacy (and in some cases lack thereof) of a few important officers and officials, and even what they read, may have had an influence on the strategy and tactics of the Boers.

Three issues are at stake. Firstly, a study of Boer reading practices gives an indication of the state of the skills-based literacy on commando. Vice versa a study of the state of literacy at the outbreak of the war gives an indication of the expected reading practices on commando. Secondly, the scattered pieces of information make us aware of what was read on commando and what sort of reading matter was available to the burghers. And thirdly, it is clear that there is a correlation between reading and class and that these practices reflect the social milieu of the men and how the reading matter influenced their attitude to the lingering war.

It was possible to investigate reading practices on commando by making a thorough study of a wealth of Boer diaries, letters and reminiscences. These were either published sources or archival material, the latter being accessions in the State Archives in Pretoria and Bloemfontein, and the War Museum of the Boer Republics in Bloemfontein, South Africa. References to reading material in these sources were carefully noted and arranged for this paper. Most sources do not mention reading matter, which is already an indication that reading was not a general pastime. As there was no censorship in the Boer forces, the keeping of diaries and the writing of letters to loved ones at home (before the British scorched earth policy was implemented in June 1900 and Boer civilians sent to concentration camps from September 1900) were surprisingly popular, although not a major pastime. Creating documents or keeping record were of course also influenced by the relative state of Boer literacy, which is discussed below.

\section{Reading practices and literacy in the war - black people and the British soldiers}

It is difficult to decide what to make of burgher reading habits and literacy if we do not know how they compared to those of other armed forces or groups of the time.

It would not be easy to find information on reading matter for the black agterryers (assistants, lit. after-riders) who accompanied the Boers on commando. Most of them were simply not literate enough or had not undergone schooling before the war to read while on commando. Exceptions were inboekselinge or oorlams (indentured labourers) some of whom also acted as agterryers on commando. Some black people had been educated at missionary stations, and they were probably able to read, but no proof of agterryers reading books or newspapers on commando has been found. What we do have, thanks to the philatelists who concentrate on postmarks on envelopes, is proof (envelopes) of three letters written by agterryers to their people on the home front in the first months of the war. The letter by Elias Matsobane to his wife, Christien, has been preserved. The envelope has a postmark from the main Boer 
laager in Natal on 16 March 1900. Of interest is that Mrs Matsobane's address is given as "Edindaal, Eerste Fabrieken, distr Pretoria, ZAR". Edendale was a Berlin Missionary Station in the Pretoria District, where Mr Matsobane must have received his education. His letter is written in the Dutch-Afrikaans that the Boers wrote at the time ${ }^{3}$ and does not say much about his experience on commando. Instead he enquires about the family health, and whether the maize was already ripe for the harvest. Three envelopes without the letters exist of Mrs Matsobane writing to her husband. This correspondence proves that Mr Matsobane who was on commando was able to read (and write), but we do not have any indication of what he read or what was available besides the letters from his wife. ${ }^{4}$

Xhosa newspaper editor J.T. Jabavu was a learned black man running his own newspaper, Imvo Zabatsundu, in the Eastern Cape, but he was far removed from the war zone. This did not prevent him from remaining critical of British policy in South Africa throughout the war. He argued that the British government had succumbed to the influence of an irresponsible war party in Britain and South Africa, and that meaningful negotiations could have taken place with the Boers if only the British government had not been persuaded that a military solution was the only alternative to a complete surrender by the Transvaal government of its internal autonomy. In his view the war represented "the very quintessence of unfairness", 5 although few black people would have shared his view.

The only diary thus far found of a black person involved in the war, is that of Sol T. Plaatje, a Rolong journalist, court interpreter, author and later politician, who was trapped in Mafeking during the Boer siege of the town. But even with his command of eight languages and working knowledge of several more, he does not make any reference in his diary to any books that he read during his stay in Mafeking. ${ }^{7}$

Plaatje does, however, quite often refer to the Official Despatches drawn up by Colonel Robert Baden-Powell from despatches he had received from black despatch runners, and the newspaper printed in the town during the siege, entitled The Mafeking Mail Special Siege Slip. His first reference to incidentally both sources of information is on 29 November 1899, which report on the Boer occupation of Colesberg. ${ }^{8}$ Of particular importance is Plaatje's inscription on 24 January 1900 , where he reports of a proclamation by Baden-Powell "that no food stores of any kind would in the future be sold to the public", and that white people were now going to buy food in rations and be compelled to buy small quantities, "the same as blacks". A delighted Plaatje learns from the Official Despatches that General Cronjé had surrendered $^{10}$ (although the Despatch mentions 7000 Boer prisoners of war instead of 4 000), and that Ladysmith had been relieved, General Buller killing 2000 Boers and taking 3000 prisoners $^{11}$ (historian J.H. Breytenbach states that Boer casualties were about 232 - 34 killed and died of wounds, 115 were wounded and 83 taken prisoner $^{12}$ ). On 30 March 1900 Plaatje refers to a protest by Baden-Powell in The Mafeking Mail of the previous day against rumours that he was starving the inhabitants. $^{13}$

Plaatje also refers to the content of a copy of the Boer newspaper, De Volksstem, of 7 December 1899, which had been sent to Baden-Powell by General Kootjie Snyman. And on 27 December Plaatje was handed a copy of the Bulawayo Chronicle of 2 December, which he calls "a very early date for any newspaper" to be brought 
into the besieged Mafeking. He complains that such a source of information "must pass through so many hands, that when one comes across it it is quite worn out and requires to be handled with the greatest care." 14 To illustrate a point on the availability of food Plaatje on 27 December quotes an incident from No. III Royal Reader. ${ }^{15}$ It is probable that he did not have the book at his disposal at the time, but it was one of the books from which he had learned English. It was used in most South African (and African) schools in the Cape Colony at the end of the nineteenth century. ${ }^{16}$

The scope of this article does not provide for an investigation into the reading practices of the British soldiers in the South African War. However, a valid comparison would be the level of literacy of both the Boers and the British soldiers at the outbreak of the war.

In Britain Forster's Education Act of 1870 had provided a framework for compulsory elementary education, and its effects were far-reaching. Tabitha Jackson points out that the literacy rate shot up from $63.3 \%$ in 1841 to $92.2 \%$ in $1900 .{ }^{17}$ Frank Emery claims that the Victorian soldiery, despite being recruited primarily from the labouring classes in town and country, was more literate than often imagined. ${ }^{18}$

According to Jackson the South African War produced a "new outpouring of writing", which was met with "an equal appetite for reading it". Edward Spiers agrees with Emery's argument that the Victorian soldiery, despite being recruited from the labouring classes in town and country, was more literate than often imagined. ${ }^{19}$

Meanwhile the British army developed its own educational requirements. From 1871 compulsory classes of five hours per week greeted new recruits, and a new fourth-class certificate of education was introduced as a minimum for all soldiers. According to the norms applied by the director-general of military education, by 1889 $85.4 \%$ of the rank-and-file possessed "a superior level of education". ${ }^{20}$ However, Spiers warns that this claim should be interpreted with care. He argues that by 1888 , over $60 \%$ of the other ranks were unable or unwilling to pass the examination for a fourth-class certificate of education, which means simple reading and an ability to complete a few easy sums - a level purportedly attainable by an 8-year old child. The results were so disappointing that the army thereupon abolished the fourth-class certificate and terminated compulsory schooling. Despite this, Spiers adds, genuine improvements in educational standards did occur: the proportion of the rank-and-file in possession of third-class certificates of education rose by nearly $30 \%$ between 1870 and 1896, and illiteracy - defined as an inability to read or write one's own name diminished sharply from $90 \%$ of rankers in 1860 to virtually nil by 1900 . In real terms, however, by the 1890 s, fewer than $40 \%$ of men had achieved more than just the barest level of literacy. Spiers quotes Skelley stating that neither the national system of education nor the provisions made by the army were particularly effective by the late 1890s. The standard reached by the majority of those in the ranks was "elementary at best". 21

In direct comparison both the average British soldier and the majority of the Boers could not claim more than a modest literacy. However, with the Boer force a reflection of society as will be seen below, there was a small upper class, whose 
literacy was remarkably high. This probably was at least on a par with the level of literacy of the British officers.

Some references can be made to the available reading matter to the British soldiers who fought in South Africa. Spiers reckons that there are many answers on the reading habits of the British soldiers on campaign in South Africa, depending on where they were. He suspects that officers may have taken Wolseley's Soldiers' Pocket Book with them. It was certainly still selling well and had seen many editions. It would at least have been easy to carry. Soldiers on the veld were continually bemoaning their isolation and lack of news about what was happening in the war, and therefore many were writing home asking for copies of local newspapers and illustrated newspapers, where possible. ${ }^{22}$

These would include the foremost newspapers of the day, since a number of prominent British war correspondents were covering the war, like Bennet Burleigh of the Daily Telegraph, "Doggy" Knight of the Morning Post, John Black Atkins of the Manchester Guardian, Henry Nevinson of the Daily Chronicle, Lionel James of The Times and G.W. Steevens of the Daily Mail. In fact, according to lists drawn up by the military censors, more than seventy authorized war correspondents were in South Africa in the early part of the war, representing more than thirty newspapers or other media outlets. Stephen Badsey estimates that actually between 200 and 300 individuals were involved in the news-gathering process in southern Africa during the war. $^{23}$ To this should be added some British pro-Boer newspapers like Review of Reviews and Reynolds Newspaper, which, were found by Boers at vacated British camping sites.

Since there are recorded incidents from the Sudan in 1898 where literate soldiers would read reports from the press to their less gifted comrades, particularly about battles in which they had recently served, Spiers believes that this practice "almost certainly continued in South Africa". 24

The garrison under Lieutenant-General Sir George White besieged inside Ladysmith had access to a popular local newspaper, published in the spirit of the siege, entitled the Ladysmith Lyre. And Rudyard Kipling's works, including his contributions to The Friend, were widely read on the South African veld. ${ }^{25}$ Where they had access to local libraries, whether on garrison duty in the Cape Colony or convalescing after injury, one would expect soldiers to have passed some of their time by reading. ${ }^{26}$

Given the boredom of much of military service, Spiers expects that soldiers would read almost anything, or share this reading with their illiterate comrades, "but they would have had more opportunities to do so in some settings, probably in the major towns or in the rear areas of the Cape or Natal, than in others". ${ }^{27}$

\section{The state of literacy on commando}

The method used for this study to determine the skills-based literacy of the Boers was to investigate the educational standards in the two Boer republics the Transvaal and the Orange Free State in the second half of the nineteenth century, and by looking at the statistics of educational reports of the two republics. 
Since almost the entire white male population of the two republics between the ages of sixteen and sixty was conscripted and the Boer force was a citizen army, it reflected an accurate social, economic and reading profile of the Boer people as a whole. On commando there were cultured burghers as well as unsophisticated ones, affluent men as well as poor people, landowners, tenants and landless bywoners (Boers rendered landless by the rinderpest of 1897 and now living on land owned by landowners), and home owners in towns as well as occupants of burgher-right stands (landless Boers who were given free stands in Pretoria by the government). There were also representatives of every occupation and profession - from physicians, jurists, teachers and merchants to clerks, farriers, carpenters and farmers. ${ }^{28}$ Farmers were by far in the majority. By the end of the nineteenth century the republics still basically reflected a rural society, with most burghers enjoying farming as their occupation. "We have ... in our ranks all sorts, from doctors to simple tenants," J.P. Bredell summarised the situation in the Pretoria Town laager (camp) outside Volksrust on 15 October 1899. ${ }^{29}$ In March 1900 Hugo van Niekerk in the prisonerof-war camp Green Point in Cape Town, echoed Bredell's words and added: "There are those who cannot sign their name (I have indeed met such a specimen), then we have men with M.A.'s, LL.B., a medical degree, those who cannot speak or understand a word of English and those who are more at home in English than in Dutch and who know a few other European languages as well." 30 Any piece of information on the reader and his reading matter is therefore important for us to assess the social and reading profile.

The education systems of the two republics showed a slow and unspectacular increase in standards since the establishment of the Transvaal in 1852 and the Free State two years later. A number of educational acts proved to be helpful along the way, but the quality of teaching was not very high. ${ }^{31}$ By 1877 the number of children of school-going age actually in Public Schools stood at $8 \%$ for the Transvaal and $12 \%$ for the Free State, ${ }^{32}$ as parents did not see a need for education, making use of the extra hands on the farm. In the Transvaal this figure had risen to $36 \%$ in $1890,{ }^{33}$ but had dropped to $20 \%$ in $1895,{ }^{34}$ while the Free State figures were $16 \%$ in 1889 and $21 \%$ two years later. ${ }^{35}$ By 1891 the school life of a child in the Transvaal was on an average but two years. ${ }^{36}$

One would expect the average of two years' schooling as an indication of the state (or lack) of literacy among the Boers. However, most Boer children received a basic education at home, which enabled them to read the Bible and sign their name.

Furthermore, despite the fact that most Boers underwent little or no schooling in the pioneer circumstances, many of the socially higher classes improved their literary standards by merely developing their intellectual skills as time went by. The case of General C.R. de Wet is an indication what could be achieved in this way. De Wet, who was born in 1854, enjoyed formal education for only a few months, ${ }^{37}$ and yet with some assistance by the Reverend J.D. Kestell - he wrote his reminiscences of the war within three weeks on board ship from Cape Town to Southampton in August 1902. It is a well-written book in Dutch with 388 pages of text, ${ }^{38}$ surely one of the classics of the South African War. An example from a younger generation was that of Roland Schikkerling, who was nineteen at the outbreak of the war, and, despite only two years' formal education, proved through his diary to be intellectually formidable. 
There was also a core of young republicans - a social elite - who underwent schooling in the Transvaal or Free State and from there proceeded to the Victoria College (the University of Stellenbosch) or the Theologian Seminary in Stellenbosch where they obtained degrees. The next step for some of them, like Lodi Krause, J.B.M. Hertzog and Japie de Villiers to name but a few, was successful post graduate studies abroad. Krause was a student of Christ's College, Cambridge in the early 1890 s as a contemporary of Jan Smuts. He obtained the post-graduate LL.B. degree which was subsequently upgraded to the LL.M. degree. Smuts, who actually came from the Cape Colony and become State Attorney of the Transvaal in 1898, excelled at Cambridge. He headed the list for all the intercollegiate examinations in law in 1892-1893 and in 1894 was first in the class in both parts of the law tripos. He entered the Middle Temple and passed the honours examination of the Inns of Court in 1894. Hertzog obtained a doctorate in law at the University of Amsterdam in 1892. De Villiers was admitted to the Middle Temple in London as barrister in 1893, after he had been awarded a senior scholarship in $1891 .^{39}$

Two burghers who kept diaries on commando and who provide us with extensive information deserve closer attention, viz. Roland Schikkerling and Jan Celliers. Schikkerling, as mentioned, was only nineteen years old at the outbreak of the South African War. He grew up in Potchefstroom and Johannesburg and enjoyed only two years of formal schooling. It is clear, however, that he was knowledgeable on a wide range of subjects. ${ }^{40} \mathrm{He}$ had a leaning towards philosophical comments, a feature that became more pronounced as the war dragged on. ${ }^{41}$ He remained a member of the Johannesburg Commando until the end of the war. In the set-piece battle phase he fought in Natal and the guerrilla phase (the last two years of the war) saw him operating in the Eastern Transvaal. His diary was published in 1964 in both English and Afrikaans. ${ }^{42}$

Jan Celliers was 34 at the outbreak of the war. He enjoyed quite a social status amongst the burghers on commando. ${ }^{43}$ His father was the first editor of $D e$ Volksstem, a pro-government newspaper in Pretoria. Jan qualified as a land surveyor in Delft and Leiden, the Netherlands, but once back in the Transvaal the work did not suit him and in 1893 he was appointed state librarian. It is not surprising that to him reading was a favourite pastime on commando. During the war he fought with the Pretoria Commando - first on the southern front around Colesberg, and then in the guerrilla phase as a member of General J.C.G. Kemp's pedestrian laager in the Western Transvaal until peace. His diary was published in 1978 by the Human Sciences Research Council in Pretoria, entitled Oorlogsdagboek van Jan F.E. Celliers 1899-1902, with A.G. Oberholster as editor. After the war Celliers became a famous people's poet, and contributed to the establishing of Afrikaans as a formal language. ${ }^{44}$

From this a picture emerges of a small number of highly literate men, mostly townsmen from the upper social strata, who found pleasure in reading any book or printed matter they stumbled upon while on commando; a larger group of adequately literate men who were eager to read newspapers or magazines or even the occasional book; a still larger group - probably the majority - of semi-literates who could read their Bibles and with difficulty make sense of a newspaper article; and finally the illiterate group, some of whom could not read at all, while most of them could probably barely read their Bibles. This remark is placed in perspective by the 
conversation in July 1900 between General J.B.M. Hertzog and German volunteer Oskar Hintrager when the latter proposed that the Boers should adopt the German system of written reports to all men. Hertzog did not believe it would work, as he felt that reading and writing was too much of a bother for the Boers. ${ }^{45}$

\section{Reading practices on commando}

In regard to reading practices in general, it is clear that the Bible was read by almost everybody. Hintrager observed among the Free Staters in August 1900 that "every burgher" had a Bible and a hymn book in his possession. ${ }^{46}$ In the afternoons numbers of burghers lay under trees reading their pocket Bibles. ${ }^{47}$ This seemed to continue until the end of the war, as Schikkerling observed in May 1902 that among the burghers, as among their forebears, the Bible remained their main reading matter. ${ }^{48}$ References to Biblical verses appear in almost every diary kept on commando.

Although the state of religion on commando ranged across a wide spectrum, from extreme piety and profound spiritual commitment to utter indifference and frivolity, ${ }^{49}$ it appears that a Dutch volunteer with the commandos, Gerrit Boldingh, could not have been too far off the mark with his observation that about three quarters of the burghers were genuine believers in the Calvinist tradition. ${ }^{50}$ It is therefore no surprise to find references in diaries and letters to important Calvinist theologians of the time. Andrew Murray Junior in particular had been influencing the spiritual life of the Boer people with his preaching and writing since 1849. In July 1901 a very dogmatic burgher observed to a fellowman on commando that Murray was a writer from whom you dared not differ in any respect, otherwise you belonged in the outer darkness. Another influence was the work of C.H. Spurgeon, an English Baptist and orthodox Calvinist, who was a major nonconformist preacher in the late nineteenth century. His influence in the Christian world was extensive because of the wide circulation of his sermons, published weekly, which were translated into several languages, including Dutch. In February 1900 a pious burgher on the Natal front received from a girlfriend an excerpt from one of his volumes of sermons, Spurgeon's Juweeltjes, which offered hope for the future however gloomy life might seem at present. A third yet probably minor influence was that of Abraham Kuyper, an eminent Dutch theologian and politician whose ultraconservative neo-Calvinist views started influencing Boer thinking in the late nineteenth century. At a religious service in the officer's tent on the northern front in November 1899 a respected burgher read very haltingly from one of Kuyper's many works. It is doubtful, however, whether Kuyper had any widespread influence on the burghers on commando. He only became a major force in their thinking in the twentieth century. ${ }^{51}$

One can assume that only a small number of burghers - the literate and socially upper class - read secular works for recreation and diversion. This is substantiated by a remark from a volunteer with the Dutch Ambulance in the war: "Reading is not a popular option on commando." ${ }^{52}$ The mental and educational level of the literates was poles apart from that of the majority of semiliterate and illiterate burghers. Jan Celliers pointed this out when he addressed such an elderly, uneducated burgher compassionately in his diary in February 1901: "Worthy old ox! With a sage nod of 
the head and the smile of one who has never awoken I am often warned by you against reading so many 'bits of paper', because it results in weightier matters - like grilling meat and cooking porridge - not receiving sufficient attention." ${ }^{, 53}$ In April 1901 Celliers admitted that when he and his companions were not occupied with cooking, reading and yet more reading constituted their main pastime. ${ }^{54}$

The erudition of the literate burghers was nothing less than spectacular. Schikkerling excelled in this regard, often making references in his diary to a wide variety of classical literature. After a heavy skirmish on 19 November 1900 he noted in his diary: "I could not help likening my position to that of Fabius, a centurion belonging to Curio's army. In the fight against Varus, before the town of Utica, as related in Caesar's Civil War Book II, Fabius running like a springbok overtook the foremost of the enemy fugitives and being found 'off-side' was surrounded and slain. The enemy from different points still fired at me whenever I became visible...",55

Ten days later, after the battle of Helvetia during which a 4.7 inch British naval gun was captured by the Boers, Schikkerling reflected in his diary that, while admiring the big gun, he thought of a line from Shakespeare: "But for these vile guns I would myself have been a soldier." ${ }^{, 56}$ And when looking at the British prisoners of war after the battle, he inscribed with a little superiority that he felt that there was not one among them who, like himself, had read the whole of Spenser's Faerie Queene, or knew by heart the Prologue to the Canterbury Tales. ${ }^{57}$

In February 1901 Schikkerling and some men were watching the enemy movements in the distance, when one Boer observed a vulture soaring overhead, looking, it seemed, for prospective corpses. Schikkerling maintained that it was the Valkyrie, one of the nine maidens of Odin, awful and beautiful, who hover over the field of battle choosing those to be slain and conducting the worthy heroes at Valhalla, the Hall of the Slain. ${ }^{58}$

An ironic and yet remarkable example of an erudite Boer is found in the reminiscences of Deneys Reitz, first written in Dutch in 1903 and published in English in 1929 with the title Commando. Reitz was from the social elite. He was the son of the State Secretary for the Transvaal, F.W. Reitz, and was educated at Grey College in Bloemfontein. He was only seventeen at the outbreak of the South African War. This was his experience after the battle of Nooitgedacht in December 1900 as he came upon two wounded British officers: "As I came up I heard one of them remark, 'Here comes a typical young Boer for you', and they asked me whether I understood English. I told them 'Yes', and the man said, 'Then will you tell me why you fellows are continuing the war, because you are bound to lose?' I replied, 'Oh, well, you see, we're like Mr Micawber, we are waiting for something to turn up' [meaning foreign intervention]. They burst out laughing and the one said, 'Didn't I tell you this is a funny country, and now here's your typical young Boer quoting Dickens.",59

Another example of the socially and intellectually privileged was the learned Nicolaas Hofmeyr, who was appointed state historian for the Transvaal to cover the war. As the son of the well-known Professor N.J. Hofmeyr of the Theologian Seminary in Stellenbosch, and himself a former Dutch Reformed Church minister, he freely quoted from Thucydides, Sophocles, Shakespeare, Wordsworth, Gray, Byron, Coleridge, Wordsworth, Longfellow and others in his book about his six months on commando. $^{60}$ 


\section{Reading matter - where obtained}

In both the set-piece battle phase and the guerrilla phase of the war reading matter was not easy to come by, despite Act No. 20 of 1898 (Clause 19) making provision for the free despatch to and from any commando of letters, newspapers and books. Before the collapse of the central postal services of the Free State and the Transvaal between March and June 1900, relatives at home supplemented the reading matter on commando with consignments of newspapers and books. In March 1900 a burgher of the Middelburg Commando at Glencoe in Natal thanked his girlfriend by letter for the novelettes she had sent: "...as usual, they are making the general round through the camp. I always first read the stories before giving them to others. You have no idea what pleasure these stories afford to many of us."61 In February 1900 the Government Printer of the Transvaal sent some books to the front. ${ }^{62}$ Copies of newspapers like The Standard \& Diggers' News in Johannesburg and De Volksstem in Pretoria, which respectively survived until late May and early June 1900, also found their way to the front, where they were circulated among eager readers. ${ }^{63}$ In January 1900 the correspondent of De Volksstem on the western front reported that the burghers were very curious about news from other fronts and that "every man" begged for a paper when the mail arrived. ${ }^{64}$

Deneys Reitz added some flavour to the way some burghers obtained books, when he and his brother Joubert officially took out some books from the library in Dundee, Natal, in March 1900, when their commando was laagered in the Biggarsberge north of Ladysmith. This was enemy country, and in his unpublished memoirs of 1903 he expressed his shame that they never returned the books. ${ }^{65}$

With meetings of debating societies a popular pastime among the literate burghers on commando, ${ }^{66}$ some burghers of the Bethlehem Commando on one occasion made the desirability of reading newspapers a topic for a debate. C.H. Olivier, son of the general of the same name, substantiated his case for the desirability of newspaper reading with the following arguments: "In this way one keeps abreast with the present events in the outside world; war can be prevented; reading makes a man; reading is company; you learn the politics of the day."67

During the guerrilla phase with its long periods of total idleness, often in remote areas and little contact with normality, it was more difficult to obtain reading material on commando. Availability therefore influenced the reading practices. Schikkerling explained in a diary entry in the Eastern Transvaal in July 1901: "Our literary taste must not be commented upon, since we have no choice."68

Books and British magazines and newspapers were unearthed in deserted or devastated homesteads and shops, vacated British camping sites and captured trains. ${ }^{69}$ While trekking past a deserted and almost demolished homestead in the Western Transvaal in November 1901 Jan Celliers discovered a large number of old magazines and books lying around in disorder. "What a find!" he wrote in his diary. "With a whole pack under my arm I caught up with the wagon and soon each passenger was sitting with a magazine in his hands - roused from boredom and not feeling the scorching sun."70

Jan Smuts informs us: "On the whole we were much hampered by want of literature, many of the boers [sic] highly educated, and one of the pleasures of 
capturing an English convoy was the number of English books found among the officers' kit." 71 Smuts also records his occasional strokes of luck in getting hold of books worth reading, amongst others an address on Habakuk I, Xenophon's Anabasis and works of Desiderius Erasmus in Latin. ${ }^{72}$

At vacated British camping sites the burghers found copies of various pro-Boer newspapers like Review of Reviews and Reynolds Newspaper. ${ }^{73}$ The editor of the former was W.T. Stead, who blamed British imperialism for the war. The Labourite Reynolds Newspaper had been banned in South Africa by the British military authorities because of its outspoken opposition to British imperialism in South Africa, which it described as "the greatest crime of the century". ${ }^{74}$ Burgher P.R. de Villiers believed that these pro-Boer newspapers had been left at the campsites deliberately by well-meaning British soldiers for their information. ${ }^{75}$

In an interesting twist State Secretary F.W. Reitz learnt from a British newspaper found in a captured train and a copy of Review of Reviews picked up on the battlefield that his wife and younger sons from whom he had not heard for a long time were safe and sound in the Netherlands. The newspaper reported that the British Prime Minister, Lord Salisbury, at the request of two British parliamentarians who had met Reitz's wife in the Netherlands, had agreed to send Reitz a telegram under the white flag that his family was fine, but that Mrs Reitz had declined the offer. The Review of Reviews contained a photograph of the young Reitz children in the Netherlands. ${ }^{76}$

Informal libraries with mutual loan systems were established among some of the literate burghers. "It is amazing how one comes by a book here, a magazine there," the Reverend J.D. Kestell recalled about the library which President M.T. Steyn of the Free State carried with him in a cart in $1901 .^{77}$ Jan Celliers, who, as mentioned above, had been the state librarian in Pretoria before the war, took pride in his commando duty as a temporary librarian with the laager of pedestrians in the guerrilla phase in the Western Transvaal. ${ }^{78}$ In the Eastern Transvaal Roland Schikkerling and his friends formed a circulating library with the books they acquired in their many skirmishes, "and each member carries a book in his saddle bag", he noted in his diary. $^{79}$

\section{6. "What's the use of all your damn books"}

Among cultured burghers and social elite there was undoubtedly a need for good literature. In August 1901 Schikkerling was so delighted about two volumes of William Shakespeare found at a deserted trading post in the Eastern Transvaal that he allowed the porridge to burn. ${ }^{81}$ Dietlof van Warmelo, brother of Johanna Brandt (author of The Petticoat Commando), remembered how he and his friends in the Western Transvaal often yearned on the weary, monotonous, stultifying rides during the guerrilla phase for the works of a writer like J.C.F. von Schiller. ${ }^{82}$ These friends would include members of their debating society, like Jan Celliers, Morti Malherbe, later professor of law at the University of Stellenbosch, and J.F. Naudé, theological student at Stellenbosch before the war and after the war an influential Dutch Reformed Church minister (and father of the anti-apartheid activist, Beyers Naudé). ${ }^{83}$ 
Celliers in fact often referred to "we", not meaning the royal plural, when describing the delight of reading. 84

Reading was an escape for the burghers from the horrors of war, the hardship, heat, cold, want, hunger, boredom and deep concern and excruciating longing for beloved ones who were separated from them. A sensitive man like Celliers revealed this on a number of occasions. After a terrible night, 19 February 1901 was a really miserable, wet, cold, day in the Western Transvaal. "Early in the morning I began to shut myself off psychologically from this horrible day by completely absorbing myself in a book that I had found lately. Delightful escape! I therefore saw or felt little of the wetness and cold around me," he scribed. ${ }^{85}$ This, in psychological terms, is an example of General Resistance Resources (GRR), where Celliers' reading was a resource which assisted him in coping with his circumstances. ${ }^{86}$

For Schikkerling too books were an important resistance resource to cope with the war, and on several occasions during the second half of 1901 in the Eastern Transvaal he mentions the finding reading material. In July 1901 he tells us: "All day in the shade of a thorn tree I lie reading a book called 'First Person Singular'; 'The Severed Hand', and 'Plutarch's Lives of Caesar and Alexander', have still to come. ${ }^{87}$ In October 1901 he rejoices that he has found some books in a deserted farmstead, "among which are Poe's inimitable tales". ${ }^{88}$ At the end of January 1902 he and a group of friends bide their time on a farm where the food for horse and man was plentiful. But while his comrades were hunting for meat and honey he lay on the soft grass, reading a book which he carried in his saddle-bag. ${ }^{89}$ He obviously found more in the reading of books than just passing the time. He was constantly adding to his knowledge, expanding the horizon of his limited world on commando and using this as a means to escape from the harsh realities of a hopeless war. The value of reading books should therefore be regarded as an important instrument in helping Schikkerling and other burghers in the small intellectual groups, to maintain a balanced outlook on life, despite its pressures.

Jan Smuts explained: "In case like ours where there was so much continual disappointment and mental suffering quite apart from the physical privations, books and all healthy forms of mental pabulum were great desideratums." 90

However, reading could also have the opposite effect, and that on the same person who had experienced reading as an escapism. On another "cold, miserable, rainy day" in November 1900 reading a book made Celliers remark: "What a mournful feeling I experienced when at last I put the book down: not only because I was physically separated from my beloved ones, but also because I had banned them from my mind by having company with entirely alien people and scenes. I reproached myself and for a while I felt terribly sorrowful." 91 On a day in August 1901 reading again did not alleviate his pitiful state. He was herding some cattle in a deserted little valley, but he was not able to read the book he had taken along: "The loneliness in these wild hills oppressed me and made me long more than ever for the end of all this. Repeatedly I found myself praying and pleading to God for deliverance, for peace, for the happy reunion with her and the children." 92

The reading of newspapers was extremely welcome for those burghers who wanted to know what was going on in the outside world, particularly in the guerrilla phase when the commandos were scattered all over the operational area. Reaction to 
the news varied. On 28 December 1900 P.J. du Toit noted in his diary in the Western Transvaal that he had read a number of Australian newspapers, which painted a gloomy picture for the Transvaal. With anxiety he asked: "What is there now to save us? I think nothing, and the best thing is to submit which I shall do very soon." Five months later he surrendered to the British. ${ }^{93}$ A different experience was that of Frits Rothmann, who on 13 April 1901 was handed a copy of The Cape Argus Weekly of 20 March which had been taken from a derailed British train on the Pretoria-Delagoa Bay railway. Having not heard any news from the outside world for a long time, the prospect of an evening spent reading the newspaper seemed like a feast to Rothmann. ${ }^{94}$

\section{Book reviews}

Fascinating are the assessments a few erudite burghers made in their diaries of the specific books they had just finished reading. Celliers proved to be the most eager reviewer. In February 1901 he found J.V. Scheffel's historical novel, Ekkehard (1855), "beautiful, very well written. One of the works I shall remember." Nothing was exaggerated, he stated, nothing annoyed. It was a masterful junction of various scenes into a pure and harmonic whole, wherein the main character always showed to better advantage. And yet the last part pleased Celliers less, i.e. from the moment that Ekkehard escaped from the Hohentwiel Mountain. Celliers imagined that the author would have given the story a different ending if he had been bound less by the biographical facts. ${ }^{95}$ In April 1901 he indirectly blamed gold as the cause of the South African War when he observed that the following words from a Canto by Dante (which he had found on an old British campsite) were underlined: "Not all the gold that is beneath the moon, or even hath been, of these toil-worn souls might purchase rest for one." (Canto VII, lines 65-67). ${ }^{96}$ The next day Celliers compared Elizabeth Prentiss' Stepping Heavenward with R.S. Hitchens' Green Carnation and Walter Besant and James Rice's The Golden Butterfly. The first was the positive, the second the negative way of treating more or less the same issue. He found Green Carnation a bit exaggerated in presenting the original zeitgeist and felt that it demanded some knowledge of modern English literature. The Golden Butterfly was a similar kind of book, satirising money and the misapplication thereof. ${ }^{97}$

In August 1901 Celliers criticised M.S. Cummins' Der Lampenputzer (the 1854 English edition was entitled The Lamplighter). At the start he thought he would enjoy the story of an interesting, refreshing life of a girl, an account of the adventures, struggles and victories of a good person. This the book partly offered. But, Celliers asked himself, why the everlasting, dull, childish dragging in of those phenomenal, wonderful farewells and sensational re-encounters, that pretty ending? ${ }^{98}$ In December 1901 Celliers decided that B.M. Croker's Lady Hildegard, of which he had read the German translation, was "very entertaining and well-written - recommendable". 99 In January 1902 J.F. Helmers' De Hollandsche Natie, in Zes Zangen (1871) made an impression on Celliers "of an impassioned singer who had intoned his song too high, every time doing his utmost to bring out the highest notes, but time and again losing his voice to transcend into a glowing, tiresome hissing that ends abruptly due to a lack 
of breath. But for that reason alone the song deserves to be held in esteem, as the effusion of a glowing chauvinistic heart that wants to arouse similar passion with his compatriots." 100

Roland Schikkerling's encounter with two volumes of Shakespeare in August 1901 made him philosophise in his diary: "I felicitate myself that I am able to read this greatest of all poets in his own tongue, and, incidentally, that, of all animals, I am privileged to be man, and live in the present time, hard as it is, and am heir to all the ages..."101 In July 1900, having read passages from the Bible, he wondered why he had not discovered earlier in his life what beautiful reading "this most divine, and, at the same time, most human of books" made. He found the poetry of the book of Job probably the highest literary achievement of the Hebrews: "The teachings of the Bible are interwoven with, and hold together as a magnificent tapestry, our highest civilization. Taken away, the whole fabric would be impaired and the threads and strands forming every beautiful pattern, drawn out, leaving our civilization shredded and tangled. Read in Dutch, its grandeur and majesty of language, to my mind, can never be surpassed." 102

On the night of 7 January 1901 The Great Boer War by Arthur Conan Doyle, describing the lingering war since 1899, was looted from a fort during the attack on Belfast and other British garrisons in the Eastern Transvaal. State Artillerist Gustav Preller - another member of a socially privileged family, his father being commandant of the Pretoria Commando on the Colesberg front - thought it "a fairly sound description, although not free from exaggeration and understatement". 103

Other classics and non-classics from famous and not so famous authors come across in diaries, letters and reminiscences of life on commando include Julius Caesar (De Bello Gallico), Plutarch's Lives of Caesar and Alexander, extracts from Seneca in English, John Bunyan (Pilgrim's Progress in Dutch), Sir Walter Scott (Waverley), Wilkie Collins, Tolstoi (Anna Karénina and War and Peace in German), a biography of Savonarola, The Prisoner of Zenda, The Severed Hand, Augustin Scribe, Fritz Reuter, and Justus van Maurik (Krates). ${ }^{104}$

\section{Literacy versus the school of the veld}

In this assessment of the reading practices and the state of literacy on commando during the South African War of 1899-1902, a picture has emerged of a small number of highly literate men, a social elite amongst the burghers; a larger group of adequately literate men; a still larger group of semi-literates; and finally the illiterate group. Diaries, letters and reminiscences mainly from the first two groups have given a good indication of the reading practices of these burghers on commando. Reading from the Bible was a general experience from basically all social classes. The erudite burghers were - as could be expected - mainly townspeople, most of whom were from the social elite among the Boers. One would expect a more secular outlook from the urbanized readers, but this is not the case - of the socially privileged burghers quoted, only Deneys Reitz could be regarded as a secularized individual, with an aversion to the "theatrics" of religiously pious Boer officers. ${ }^{105}$ 
Certain categories of reading material on commando have been distinguished, viz. the Bible, newspapers and magazines, and books. It was pointed out that everything depended on what reading matter was available in both the set-piece battle phase of the war (lasting from October 1899 to August 1900), and the guerrilla phase (from September 1900 until May 1902). It became clear that sources for making reading matter available in the set-piece battle phase included relatives at home and the governments of the Transvaal and the Orange Free State. Deserted and devastated homesteads, vacated British camping sites and captured trains, provided the Boers with reading matter in the guerrilla phase, and even libraries were built up from available stock. Fascinating were the assessments a few burghers made in their diaries of the specific books they had read. A comparison of the state of literacy between the burghers and officers on commando and various other contemporary combatants, and the availability of sources to these groups place the Boer experience in perspective.

Finally, some important questions need to be answered: Did literacy (or illiteracy) influence military decision-making or troop morale? Were certain works, like the Bible, and their interpretation, making some impact on the battlefield? Was the school of the veld - the practical experience the Boers had gained in their pioneer existence before the war - more successful on the battlefield and in planning strategy and tactics than literacy? We need to distinguish between the position of the ordinary burghers and that of the officers.

It is clear that the ordinary burghers - both literate and illiterate - had no say in military decision-making. The brilliant minds of a Jan Celliers or a Roland Schikkerling or a Deneys Reitz had no share in the planning of strategy and tactics. However, literate and semi-literate burghers - except the most cynical - were willing targets for the propaganda that the Boer newspapers and the official war reports spread throughout the war, and their authority and views could in turn easily influence the illiterate burghers. The newspapers published official military notices and factual accounts of military operations, sometimes exaggerating enemy casualties or setbacks and concealing their own reverses. They proved useful in supplying information and promoting the Boer cause. Official war reports compiled by the Boer governments and disseminated to the various commandos in the field were a powerful means of propaganda and boosting troop morale. ${ }^{106}$

We have seen above that at least with the literate burghers troop morale was boosted by the opportunities to read whatever reading matter was available. Books and magazines were an important resistance resource to cope with the war. They were essential to maintain a balanced outlook on life, despite its pressures.

A careful analysis has shown that the Bible and the burghers' Calvinist religious perceptions clearly had an impact on commando. One of the outstanding features of the burghers' religious experience on commando was that faith and nationalism were intertwined. Many of them compared the Afrikaner people with Israel. This does not necessarily mean that they saw themselves as a continuation of the chosen people although some statements hint at this - but they saw their dire straits as similar and drew strength from God's deliverance of Israel.

Against this background it is understandable that ministers and other Bible readers on commando usually chose Old Testament texts depicting the suffering of individuals or of the people of Israel. The never-ending hardships of the burghers on 
commando and the impact of the British concentration camps for Boer civilians no doubt influenced their choice of readings, since these strongly emphasized the message of deliverance from the enemy. ${ }^{107}$

Burgher Nico Hofmeyr indeed wondered whether this Old Testament faith was not at the root of the heroic courage and inflexible pertinacity displayed by the hard core of Boers. ${ }^{108}$

These Calvinist burghers had a strong sense of vocation - that God would not take their hard-won country from them and give it to the "godless enemy". This sense of vocation gave rise to a number of religious convictions. The first was that they were fighting for a holy and just cause. Along with this conviction was the belief that God was on their side. Many remarkable feats of arms throughout the war reinforced this belief. A third notion was that they should trust in the Lord, but should also do their duty - work and prayer go hand in hand. A fourth conviction was that, notwithstanding the greatest suffering, God would grant them deliverance in his own time - often seen as victory in the war rather than in the life hereafter. Finally in typical Calvinist fashion, the sovereignty of God was a vital tenet to the burghers on commando. ${ }^{109}$

It is a moot point whether literacy (or illiteracy) of the officers influenced military decision-making. The same goes for the question whether the school of the veld was more successful on the battlefield and in planning strategy and tactics than literacy. By "school of the veld" we mean that the Boers grew up under pioneering circumstances, learning about hunting and nature, experiencing little or no official schooling and enjoying some private tutoring by parents in reading - particularly the Bible - and writing.

Generals Jan Smuts and Barry Hertzog had the best academic qualifications of the Boer officers, incidentally both in law, as has been pointed out above. Their erudition was of the highest quality and prompted them independently to propose an offensive Boer strategy before the outbreak of the war that contained remarkable similarities. In a memorandum to the Transvaal's Executive Council on 4 September 1899 Smuts forecast that the inevitable war would be long and bloody. Quick military action was necessary. This should be done by taking the offensive before the British force in South Africa - at that stage about 15000 men - was markedly strengthened. At that moment the Transvaal and Free State could muster about 40000 burghers with immediate effect. The goal should be to invade Natal and reach Durban before British reinforcements could arrive, and to cut the railway-line between the Cape Colony and Rhodesia. This would encourage the adjacent districts in the Cape Colony to rise against the British authority and form a third republic. ${ }^{110}$ Hertzog proposed to President M.T. Steyn of the Orange Free State that in the event of war, the republics should immediately act offensively by invading the Cape Colony and Natal - and occupy the most strategic positions. In this way the Boers would take stronger positions than those available in the republics, while the contest would be on enemy ground and his supplies could be tapped. ${ }^{111}$ Eventually these proposals of Smuts and Hertzog were executed, but only partially and too late to have a lasting positive effect on the Boer military effort.

Smuts, who was appointed combat-general in December 1900, made a terrible blunder in his first battle at Nooitgedacht, when he failed to block the retreat of 
Major-General R.A.P. Clements. It was only his apprenticeship as a military leader in guerrilla warfare under General Koos de la Rey that made him the outstanding general that he became famous for. ${ }^{112}$ There is no proof that his erudition had any direct influence on his strategy or tactics, but it probably did. It is ironic that he read Xenophon's Anabasis on commando, which recounts Cyrus' long march with 10000 soldiers to the Black Sea and back in 401-399 B.C.E., because there is no indication that it had an effect on his own long march from the Transvaal through the Free State and the Eastern and Western Cape to the northwestern Cape between August and December 1901.

The case of Hertzog is probably our best proof of an officer's erudition assisting him on the battlefield. We know that his extensive library before the war contained a complete set of the works of the Scottish philosopher and historian Thomas Carlyle and that he was attracted by the deeds of great men in history, like Marlborough, Napoleon and Blücher. He had the habit of reading critically, underlining with his pencil many key sentences or passages. ${ }^{113}$ In this respect Carlyle's Frederick the Great played an important role in forming the military outlook of Hertzog, a man who never had had a day's military training. ${ }^{114}$ The principles Carlyle emphasized in Frederick the Great were ideal for the Boers' guerrilla warfare, and Hertzog applied these after his appointment as assistant chief-commandant in the southwestern Free State in September 1900. These included the notions that one should not be ashamed to flee when driven into a corner by the enemy; one should personally choose the time and place for battle and not be forced upon in this by the enemy; a head-on clash against superior numbers should be avoided; the highest possible mobility is necessary in order to strike and retreat with speed; and the contest should be conducted as far as possible in the enemy's territory in order to tap his supplies. ${ }^{115}$

With their legal backgrounds Smuts and Hertzog played a major role in the discussions leading to the Peace of Vereeniging on 31 May 1902. On the question whether the sixty Boer delegates to the peace talks were bound by the mandate that they had received from their commandos to retain republican independence, Hertzog determined - and Smuts concurred - that the delegates were plenipotentiaries who could vote according to their own conviction. This opened the door to peace. They also played a vital role in the tough negotiations with Lord Kitchener and Lord Milner about the final terms of the agreement. ${ }^{116}$

Opposed to these erudite officers were the leaders who had received little or no formal education, relying on the "school of the veld" to guide their conduct. They were all men who in later years acquired literacy in some degree and were able to express themselves on paper. Two prominent generals of the old school who displayed a lack of understanding modern warfare against the formidable Imperial Britain, and whose military conduct remind of nineteenth century-warfare against black communities with primitive weapons, were Lukas Meyer (born 1846) and Kootjie Snyman (born 1838). Meyer operated on the Natal front and Snyman was in charge of the siege of Mafeking on the western front. Both were released of their military duties soon after the British occupation of Pretoria in June 1900.

However, the "school of the veld" was not necessarily an obstacle to impressive military conduct, just as literacy was no guarantee for success on the battlefield. Generals Koos de la Rey and Christiaan de Wet were fine examples. De la Rey had 
no formal schooling, but he received a solid education from his parents. De Wet had only a few months of formal schooling. Yet they both applied their practical knowledge of survival to the advantage of the Boer cause. It was de la Rey who saw the merit of building trenches not on top of the hills, where the British expected the Boers, but in front of the hills that led to the massacre of the Scottish regiments at the Battle of Magersfontein in December 1899. De la Rey had difficulties in persuading his superior in rank from the old school, General Piet Cronjé, to accept these tactics, and it was left to President Steyn to intervene and approve de la Rey's plans. But de la Rey excelled in particular as a guerrilla leader, attacking the enemy from three sides in surprise swoops, as his victory over Lord Methuen at Tweebosch in March 1902 testified.

In one of the most remarkable victories of the war, de Wet had his artillery open fire from the hills to the east of Brigadier-General R.G. Broadwood's camp at Sannaspost in March 1900; like in a big game hunt de Wet waited with his burghers in ambush in the banks of the river to the west of the camp, and had the satisfaction of seeing the British troops fleeing away from where the bombardment was coming and straight into the firing line of the Boers hiding in the river bank. These were not tactics found in any textbook before the war, but success born from the experience of hunting and survival in the veld.

It is clear that literacy did not necessarily guarantee more success on the battlefield and in planning strategy and tactics than the experiences learnt from the school of the veld. Military competence depended not so much on erudition as the inherent qualities of the officer.

Financial assistance from the National Research Foundation in South Africa (Incentive Funding) is gratefully acknowledged.

\section{END NOTES}

\footnotetext{
${ }^{1}$ See Fransjohan Pretorius, Life on Commando during the South African War 1899-1902 (Cape Town: Human \& Rousseau, 1999), pp. 111-121.

2 https://nces.ed.gov/naal/fr_definition.asp

${ }^{3}$ For the Dutch-Afrikaans that the Boers wrote on commando see Fransjohan Pretorius, "Afrikaans as spreek- en skryftaal op kommando gedurende die Anglo-Boereoorlog", Tydskrif vir Letterkunde, (XXXVIII, 3/4), August/November 2000, pp. 47-54. For Boer postal services on commando see Fransjohan Pretorius, The A to Z of the Anglo-Boer War (Lanham, Scarecrow Press, 2009), pp. 343-345.

${ }^{4}$ E-mail correspondence, Joh Groenwald - Fransjohan Pretorius, 18 May 2016.

${ }^{5}$ Peter Warwick, Black People and the South African War 1899-1902 (Cambridge: Cambridge University Press, 1983), p. 112.

${ }^{6}$ See Bill Nasson, The War for South Africa (Cape Town: Tafelberg, 2010), p. 51.

${ }^{7}$ John Comaroff, The Boer War Diary of Sol T. Plaatje: An African at Mafeking (Johannesburg:

Macmillan, 1973).

${ }^{8}$ Ibid., 29.11.1899, pp. 19-20.

${ }^{9}$ Ibid., 24.1.1900, p. 78.

${ }^{10}$ Ibid., 8.3.1900, p. 110.
} 
${ }^{11}$ Ibid., 13.3.1900, pp. 112-113.

12 J.H. Breytenbach, Die Geskiedenis van die Tweede Vryheidsoorlog in Suid-Afrika, Vol. III (Pretoria:

Government Printer, 1973), pp. 553-554.

${ }^{13}$ Comaroff, Plaatje, 30.3.1900, p. 129.

${ }^{14}$ Ibid., 28.12.1899, p. 53.

${ }^{15}$ Ibid., 27.12.1899, p. 52.

${ }^{16}$ Ibid., note 77, p. 154.

${ }^{17}$ Tabitha Jackson, The Boer War (London: Channel 4 Books, 1999), p. 80.

${ }^{18}$ Frank Emery, Marching over Africa: Letters from Victorian Soldiers (London: Hodder \& Stoughton, 1986), pp. 18-19; Edward M. Spiers, The Victorian Soldier in Africa (Manchester: Manchester University

Press, 2004), p. 2.

${ }^{19}$ Emery, Marching over Africa, pp. 18-19; Spiers, Victorian Soldier, p. 2.

${ }^{20}$ Spiers, Victorian Soldier, p. 3. See A.R. Skelley, The Victorian Army at Home: The Recruitment and

Terms and Conditions of the British Regular, 1859-1899 (London: Croom Helm, 1977), pp. 89-90.

${ }^{21}$ Spiers, Victorian Soldier, p. 3.

${ }^{22}$ E-mail correspondence, Edward M. Spiers - Fransjohan Pretorius, 29.8.2012.

${ }^{23}$ Stephen Badsey, "War Correspondents in the Boer War", in John Gooch (ed), The Boer War: Direction, Experience and Image (London: Frank Cass, 2000), pp. 189-191.

${ }^{24}$ E-mail correspondence, Edward M. Spiers - Fransjohan Pretorius, 29.8.2012.

${ }^{25}$ Edward M. Spiers, "Kipling and Tommy Atkins in the South African War", Kipling Journal, Vol. 85 (April 2011), pp. 56-65.

${ }^{26}$ E-mail correspondence, Edward M. Spiers - Fransjohan Pretorius, 29.8.2012.

${ }^{27}$ E-mail correspondence, Edward M. Spiers - Fransjohan Pretorius, 29.8.2012.

${ }^{28}$ Pretorius, Life on Commando, p. 252.

${ }^{29}$ Transvaal Archives Depot (TAD), A1361, Dinah Badenhorst Accession, C, Letter, J.P. Bredell - D.

Badenhorst, 15.10.1899.

${ }^{30}$ M.C.E. van Schoor (ed), "Dagboek van Hugo H. van Niekerk", Christiaan de Wet-Annale, 1, 1972, 22.3.1900, p. 49.

${ }^{31}$ E.G. Malherbe, Education in South Africa (1652-1922) (Cape Town: Juta, 1925), p. 283. This book saw a second volume for the period 1923 to 1975 published by the same author in 1977. Despite their age, both volumes remain the most important source on the history of education in South Africa.

${ }^{32}$ Ibid., p. 249.

${ }^{33}$ Ibid., p. 264.

${ }^{34}$ Ibid., 284.

${ }^{35}$ Ibid., pp. 373-374; S.F. Malan, Politieke Strominge onder die Afrikaners van die Vrystaatse Republiek (Durban: Butterworth, 1982), p. 190.

${ }^{36}$ Malherbe, Education (1652-1922), p. 249.

${ }^{37}$ M.C.E. van Schoor, "De Wet, Christiaan Rudolph", in Dictionary of South African Biography, I, edited by W.J. de Kock (Pretoria: Human Sciences Research Council, 1968), p. 233.

${ }^{38}$ C.R. de Wet, De Strijd tusschen Boer en Brit (Amsterdam: Höveker \& Wormser, 1902). The English edition was entitled Three Years War (London: Archibald Constable, 1902).

${ }^{39}$ J. Taitz, (ed). The War Memoirs of Commandant Ludwig Krause 1899-1900 (Cape Town: Van Riebeeck Society, Second Series, No. 26, 1996), pp. xix-xxiii; J. van der Poel, "Jan Christiaan Smuts", Dictionary of South African Biography, I, edited by W.J. de Kock (Pretoria, HSRC, 1968), p. 738; M.C.E. van Schoor, M.C.E. (ed), "The Diaries and Recollections of Jacob Abraham Jeremias de Villiers." Christiaan de WetAnnale, 8, 1990, pp. 5-6; J.H. le Roux et al., Generaal J.B.M. Hertzog. Sy Strewe en Stryd I (Johannesburg: Perskor, 1987), pp. 8-23].

${ }^{40}$ R.W. Schikkerling, Commando Courageous (A Boer's Diary) (Johannesburg: Keartland, 1964), p. 9 and 5.12.1901, pp. 334-336.

${ }^{41}$ A.J. McLeod, "The Psychological Impact of Guerrilla Warfare on the Boer Forces during the South African War" (Unpublished D.Phil. thesis, University of Pretoria, 2004), p. 320.

${ }^{42}$ The Afrikaans title was Hoe Ry die Boere ('n Kommando-Dagboek)(Johannesburg: Afrikaanse PersBoekhandel, 1964).

${ }^{43}$ A.G. Oberholster (ed), Oorlogsdagboek van Jan F.E. Celliers, 1899-1902 (Pretoria: Human Sciences Research Council, 1978), 20.5.1900, pp. 107-108. 
${ }^{44}$ A.J. Coetzee, "Celliers, Johannes François Elias (Jan)", in Dictionary of South African Biography, I, edited by W.J. de Kock, pp. 158-160.

${ }^{45}$ J.J. Oberholster (ed), "Dagboek van Oskar Hintrager. Saam met Christiaan de Wet Mei - September 1900." Christiaan de Wet-Annale, 2, 1973, 3.7.1900, p. 51.

${ }^{46}$ Oberholster, "Dagboek van Oskar Hintrager", 4.8.1900, p. 99.

${ }^{47}$ H. Verloren van Themaat, Twee Jaren in den Boerenoorlog (Haarlem: H.D. Tjeenk Willink, 1903), p. 53.

${ }^{48}$ Schikkerling, Commando Courageous, 11.5.1902, p. 385.

${ }^{49}$ Pretorius, Life on Commando, pp. 176-187.

${ }^{50}$ G. Boldingh, Een Hollandsch Officier in Zuid-Afrika (Rotterdam: B. van de Watering, 1903), p. 65.

${ }^{51}$ Pretorius, Life on Commando, pp. 171-172.

${ }^{52}$ TAD, A1161, South African War Accession, De Telegraaf, 13.2.1936.

${ }^{53}$ Oberholster, Jan Celliers, 17.2.1901, p. 211. My translation.

${ }_{55}^{54}$ Ibid., 2.4.1901, p. 228.

${ }_{55}^{55}$ Schikkerling, Commando Courageous, 19.11.1900, p. 98.

${ }^{56}$ Ibid., n.d., pp. 118-119. The line - originally "he would himself" - is from King Henry IV, Part I, and was uttered by the Prince.

${ }^{57}$ Ibid., 29.12.1900, p. 120.

${ }^{58}$ Ibid., 13.2.1901, p. 147.

${ }^{59}$ D. Reitz, Commando. A Boer Journal of the Boer War (London: Faber \& Faber, 1929), p. 137. The quotation is from Charles Dickens' David Copperfield.

${ }^{60}$ N. Hofmeyr, Zes Maanden bij de Commando's ('s-Gravenhage: W.P. van Stockum, 1903), e.g. pp. 12, 16, 20, 29, 79, 86, 87, 91, 94, 96, 111, 121, 133, 135, 157, 231, 240 and 340.

${ }^{61}$ Free State Archives Depot (FSAD), A14, General J.C. Smuts Collection, Letter, Philip - Winnie, 14.3.1900.

${ }^{62}$ TAD, Major A.L. la C. Bartrop Accession, Diary of unknown burgher, Pretoria Town Commando, 9.2.1900.

${ }^{63}$ TAD, A1027, Commandant C.J. Muller Accession, Diary of Muller, Vol. 2, 1900.1.16; TAD, A1271, S. Begeman Accession, Vol. 1(a), 29.3.1900, p. 18 and A1271, Vol. 1(b), 15.4.1900, p. 70.

${ }^{64}$ De Volksstem, 9.1.1900.

${ }^{65}$ Brenthurst Library, Johannesburg, MS272/2, Volume 2, pp. 182 and 183. My thanks to Gerhard Calitz for this reference.

${ }^{66}$ Pretorius, Life on Commando, p. 121.

${ }^{67}$ Private Collection, Mrs M. van Bergen, Notebook of C.H. Olivier.

${ }^{68}$ Schikkerling, Commando Courageous, 27.7.1901, p. 266.

${ }^{69}$ Ibid., 19.8.1901, p. 286; Oberholster, Jan Celliers, 17.2.1901, p. 211 and 12.4.1901, p. 233; TAD, A284, P.R. de Villiers Collection, Vol. 8, p. 156; TAD, A1173, A.W. de Waal Accession, Diary of de Waal, 12.10.1901.

${ }^{70}$ Oberholster, Jan Celiers, 17.11.1901, p. 316. My translation.

${ }^{71}$ Quoted in W.K. Hancock, Smuts, I: The Sanguine Years 1870-1919 (Cambridge: Cambridge University Press, 1962), p. 137.

${ }^{72}$ Hancock, Smuts, I, p. 37; W.K. Hancock \& J. van der Poel (eds), Selections From the Smuts Papers, I (Cambridge, Cambridge University Press, 1966), p. 409.

${ }^{73}$ TAD, A284, P.R. de Villiers Collection, Vol. 8, p. 156.

${ }^{74}$ A.M. Davey, The British Pro-Boers, 1877-1902 (Cape Town: Tafelberg, 1978), p. 166.

${ }^{75}$ TAD, A284, P.R. de Villiers Collection, Vol. 8, p. 156.

${ }^{76}$ Ibid.

77 J.D. Kestell, Through Shot and Flame (London: Methuen, 1903), p. 214.

${ }^{78}$ Oberholster, Jan Celliers, 2.11.1900, p. 161, 2.4.1901, p. 228 and 17.11.1901, p. 316.

${ }^{79}$ Schikkerling, Commando Courageous, 27.7.1901, p. 266.

${ }^{80}$ From the film Zorba the Greek, directed by Michael Cacoyannis (1964).

${ }^{81}$ Schikkerling, Commando Courageous, 19.8.1901, p. 286.

${ }^{82}$ D.S. van Warmelo, On Commando (Johannesburg: Ad. Donker, 1977), p. 54.

${ }^{83}$ J.F. Naudé, Vechten en Vluchten van Beyers en Kemp "bôkant"De Wet (Rotterdam: Nijgh \& Van Ditmar, 1903), p. 216; Oberholster, Jan Celliers, 8.3.1901, p. 219 and 14.3.1901, pp. and 220-222; van Warmelo, p. 114; Pretorius, Life on Commando, p. 121. 
${ }^{84}$ Oberholster, Jan Celliers, 17.2.1901, p. 211, 2.4.1901, p. 228 and 17.11.1901, p. 316.

${ }^{85}$ Ibid., 19.2.1901, p. 213. My translation.

${ }^{86}$ McLeod, "The Psychological Impact of Guerrilla Warfare", p. 221.

${ }^{87}$ Schikkerling, Commando Courageous, 27.7.1901, p. 266.

${ }^{88}$ Ibid., 7.10.1901, p. 313.

${ }^{89}$ Ibid., 31.1.1902, p. 349.

${ }^{90}$ Quoted in Hancock, Smuts, I, p. 137.

${ }^{91}$ Oberholster, Jan Celliers, 2.11.1900, p. 161. My translation.

${ }^{92}$ Ibid., 4.8.1901, p. 270. My translation.

${ }^{93}$ J.P. Brits (ed), Diary of a National Scout P.J. du Toit 1900-1902 (Pretoria: Human Sciences Research Council, 1974), 28.12.1900, pp. 32-33 and 31.5.1901, pp. 51-52; McLeod, "The Psychological Impact of Guerrilla Warfare", p. 221.

${ }^{94}$ M.E.R., Oorlogsdagboek van 'n Transvaalse Burger te Velde 1900-1901 (Cape Town: Tafelberg, $2^{\text {nd }}$ ed., 1976), 13.4.1901, p. 165; McLeod, "The Psychological Impact of Guerrilla Warfare”, pp. 220-221.

${ }^{95}$ Oberholster, Jan Celliers, 22.2.1901, pp. 213-214. My translation.

${ }^{96}$ Ibid., 12.4.1901, p. 233.

${ }^{97}$ Ibid., 13.4.1901, p. 233.

${ }^{98}$ Ibid., 26.8.1901, p. 281.

${ }^{99}$ Ibid., 4.12.1901, p. 322. My translation.

${ }^{100}$ Ibid., 16.1.1902, p. 335. My translation.

${ }^{101}$ Schikkerling, Commando Courageous, 19.8.1901, p. 286.

${ }^{102}$ Ibid., n.d., p. 44.

${ }^{103}$ TAD, A787, 61, Diary of Gustav Preller, 17.1.1901, p. 184. My translation.

${ }^{104}$ Oberholster, Jan Celliers, 17.2.1901, p. 211, 24.2.1901, p. 214, 2.4.1901, p. 228, 25.7.1901, p. 265;

Schikkerling, Commando Courageous, 27.7.1901, p. 266, 14-15.4.1902, p. 380; FSAD, A14, General J.C. Smuts Collection, No. 53, Unknown - Lady friend, 10.3.1900; Kestell, Through Shot and Flame, pp. 214215.]

${ }^{105}$ Reitz, Commando, p. 140.

${ }^{106}$ See Fransjohan Pretorius, "Boer Propaganda during the South African War of 1899-1902", The Journal of Imperial and Commonwealth History, 37(3), September 2009, pp. 399-419.

${ }^{107}$ Pretorius, Life on Commando, pp. 176-178.

${ }^{108}$ Hofmeyr, Zes Maanden bij de Commando's, p. 249.

${ }^{109}$ Pretorius, Life on Commando, pp. 178-182.

${ }^{110}$ Hancock \& Van der Poel (eds), Selections from the Smuts Papers, I, Memorandum, 4 September 1899, pp. 322-329.

${ }^{111}$ M.C.E. van Schoor, Genl. J.B.M. Hertzog se Bydrae in die Anglo-Boereoorlog (Gen. J.B.M. Hertzog Memorial Lecture, Bloemfontein, 19 November 1986), p. 9.

${ }^{112}$ Hancock, Smuts, I, p. 124.

${ }^{113}$ P.C. Coetzee, "Generaal Hertzog se Boekery", Hertzog-Annale, 2(3), March 1954, pp. 2-3.

${ }^{114}$ Van Schoor, Hertzog se Bydrae, pp. 9 and 19; Oswald Pirow, James Barry Munnik Hertzog (Cape Town, Timmins, 1930), p. 30.

${ }^{115}$ Van Schoor, Hertzog se Bydrae, pp. 19-20.

${ }^{116}$ J.D. Kestell \& D.E. van Velden, The Peace Negotiations Between the Governments of the South African Republic and the Orange Free State, and the Representatives of the British Government, which Terminated in the Peace Concluded at Vereeniging on the $31^{\text {st }}$ May, 1902 (London, Richard Clay, 1912), passim. 